\title{
Citizen Science as a Bridge to the Violence Prevention in the Social Field School
}

\section{Oksana Havryliv}

Faculty of International Relation, Ivan Franko University,

vul. Universytets'ka 1, Lviv, Ukraine

E-mail: oksana.havryliv@univie.ac.at

Copyright owned by the author under the terms of the Creative Commons AttributionNonCommercial-NoDerivatives 4.0 International License (CC BY-NC-ND 4.0).

The article is based on the science communication project "Verbal Aggression in the Action Field School: Causes, Forms, Violence Prevention" (FWF), which the author worked on from 14.03.2018 to 13.09.2019 at 12 schools in Vienna (a total of 27 classes, 670 pupils, 11-17 years old): 5 secondary schools, 5 NMS/WMS (New Middle Schools), 1 BSV (student council), 1 BHAS/BHAK (Commercial High School) and the Wien Josefstadt Prison (11 pupils) with active participation of the pupils in the research process. 


\section{Project and its goals}

All science communication programs aim to awake the interest in science and scientific research. In the case of our project, it was not difficult to get the citizens interested in research, because it was a topic that was relevant to our everyday life in general and to school-related issues in particular, and aroused lively interest from the students. Even removing the taboo on the topic, the fact of being able to research the taboo vocabulary (And should we really research the swear words? or Is it possible to research something like that? were the frequently asked questions at the first meeting), has a violence preventive effect. The frequency with which pejoratives are used is directly related to their taboo status. A good example of this is Russian, which, despite the traditionally strong taboo of pejoratives, not only has a rich pejorative vocabulary, but also a linguistic variety (mat) that is based exclusively on pejorative lexemes and their derivatives and is also referred to as parallel language.

Regardless of the fact that verbal aggression occurs more frequently than physical aggression (every second schoolchildren in Vienna experienced verbal violence, while a quarter was affected by physical violence), it is reflected in school violence prevention measures and in information brochures for teachers/kids/parents very insufficient. As a result, verbal violence is not anchored in the students' consciousness as an independent form of violence. The experiences I made with Viennese schoolchildren confirm previous research results (Zuba 2006: 14): the adolescents often only identify verbal violence as such after introducing introductory questions such as "Are only the blows/is only the physical act hurtful?" or when asked explicitly about the use of aggressive speech acts. When answering the general question "What is violence?", they spontaneously think of physical violence (Gewalt ist wenn mich jemand haut/schubst/zwickt) and does not associate offensive statements with the hurtful effect - like an answer to the question "Why do you curse?" demonstrates: "Weil ich wütend werde und keinen verletzen möchtedeswegen schimpfe ich".

In the course of the research process and in lively discussions, children and young people were made aware of the fact that violence takes many forms and that linguistic actions can be just as violent as physical ones and can also be acts of violence.

The main objective of the project is to conceive the phenomena verbal aggression/verbal violence in the social field school through common research and mutual exchange regarding causes, forms and functions of verbal aggression/violence, intercultural peculiarities and violence preventive measures. 


\section{Project progress}

In our project, science communication and citizen science went hand in hand. The project involved the following activities:

- Meeting with pupils (2 hours): age-appropriate introduction to the topic, presentation of data collection, data systematization and data analysis methods, choice of topics and formation of working groups.

- Independent research phase in the working groups and preparation of short presentations (if necessary - with the support of teachers) (1 month);

- Interactive workshops "Verbal aggression in schools" with the pupils (age-appropriate design for two groups: 10-13 and 14-17 years old). Duration: 2 hours. Based on the research carried out by the pupils, causes, forms and functions, the perception of and reactions to verbalaggressive speech acts were talked about and the possibilities of non-violent communication in everyday life discussed.

Research topics:

- Why is there abuse in everyday school life?

- Where and with whom are they scolded?

- How is the scolding reacted to? Which reactions contribute to defusing and which - to worsening the conflict situation?

Depending on the class, topics such as "How do you scold?", "How do girls/boys scold" etc. were added. The question "How can we communicate non-violently?" was a central theme in all research topics.

After the pupils themselves had been able to appear in the role of researchers and had researched the causes, forms and functions of verbal aggression in everyday school life, we jointly designed non-violent models of communication/expression of emotions from a certain distance and discussed productive strategies for dealing with verbal aggression and (negative) emotions.

As can be seen from the description of the project activities, the citizens were involved in all research stages:

Choice of research topics

Formation of hypotheses

Data collection

Data evaluation and analysis

Presentation 
Citizens also had the opportunity to contribute to the current discussion about the differentiation between "verbal violence" and "verbal aggression".

\section{Project results}

\subsection{The functional spectrum of aggressive speech acts}

\begin{tabular}{|l|l|}
\hline \multicolumn{1}{|c|}{ CAUSE } & FUNCTION \\
\hline $\begin{array}{l}\text { Swear as fun to make others laugh: } \\
\text { Wir schimpfen weil es lustig ist! }\end{array}$ & Carnival-style function \\
\hline Boredom, lack of attention & Provocative function \\
\hline $\begin{array}{l}\text { In response to an abuse: } \\
\text { Weil ich mich mit Wort verteidige }\end{array}$ & Protective function \\
\hline $\begin{array}{l}\text { Habit, insufficient linguistic expression: } \\
\text { Weil es uns einfach herausrutscht! }\end{array}$ & Expletive Function \\
\hline $\begin{array}{l}\text { To demonstrate your own linguistic creativity } \\
\text { and coolness }\end{array}$ & Self-representative function \\
\hline $\begin{array}{l}\text { To demonstrate belonging to the group in which } \\
\text { the scolding takes place }\end{array}$ & Corporate function \\
\hline To get in touch & Contact-making function \\
\hline $\begin{array}{l}\text { To reinforce a statement/a request: } \\
\text { Damit die Person weiß, dass es mir ernst ist }\end{array}$ & Expressive function \\
\hline $\begin{array}{l}\text { Damit i niemand in die Gosch' } n \text { hauen muss. } \\
\text { beleidigt und ich nicht mit Schlägen, sondern } \\
\text { wörtlich (statement in original form) }\end{array}$ & Substitutive function \\
\hline
\end{tabular}

The causes and functions of aggressive speech acts listed in the chart were sorted out by Citizen and given appropriate function names by the project manager. On the other hand, the Citizen only became aware of some functions in cooperation with me as the project manager:

- To test the steadfastness of new students

- Fear or coping with uncertainty: e.g. the fears that are characteristic of this age are ventilated with the help of swear words from the sexual sphere, which are much more present in 
youth languages than in the adult group. The same applies to the swear words that refer to the outside.

During independent research into the causes of verbal aggression, the students discover a wide range of functions that the use of aggressive speech acts fulfills and determine that the offensive intention (which is not only used in everyday life but also by linguists primarily the verbal aggression) plays a subordinate role. More knowledge about the range of functions and causes of verbal aggression can move students to self-reflection and empathy (both toward others and toward themselves); it can change their linguistic behavior; and it can help them to respond appropriately to verbal aggression.

At the same time, during the course of the research, the Citizen found that verbal violence can also be exercised with linguistically neutral means, namely in the form of:

- ironic statements;

- gossip, spreading false information about a person;

- use of statements that correspond to the real situation from which the addressee is suffering: Dein Papa hat euch verlassen!

\subsection{Intercultural characteristics of the expression and perception of verbal aggression.}

For the Viennese schools, as places of linguistic diversity, the consideration of intercultural peculiarities in the expression and perception of emotions is important as well as reactions to verbal aggression.

In a joint research process, we formed a hypothesis with Citizen that the key to intercultural understanding lies in taking tabs and concepts of honor into account in different cultures. This is because not only the utterance, but also the perception of verbal aggression and reactions to verbal statements are connected:

Schimpfwörter rutschen uns einfach so heraus. (for the expletive use of Jebem ti majku/fuck your mother)

Am schlimmsten empfinden wir, wenn unser Land, unsere Mütter, unsere Familien beschimpft werden ". (4 girls with Serbian mother tongue)

Wenn ich eine Beschimpfung ignoriere, bin ich kein Mann!!! (Boy of Chechen origin)

Knowing what is perceived as particularly offensive in a culture or how to react to verbal aggression enables certain expressions to be avoided and de-escalating reactions in conflict situations. 


\section{Project impact and perspective.}

The positive effects of Citizen's preoccupation with verbal aggression/violence are diverse and long-term. The expansion of "emotional intelligence" (Goleman 1995), which foresees the skillful handling of one's own and other people's emotions and feelings, promotes nonviolent communication not only in everyday school life, but also in the extracurricular area, in the family circle and in later professional life.

The results of this project revealed the necessity of a complex approach to the phenomena of "verbal aggression and verbal violence at school", which requires the involvement of different school partners - teachers, peers, parents/guardians and school psychologists - which among other things contribute to the cooperation "school - family".

\section{References}

[1] D. Goleman, Emotionale Intelligenz, Hanser, München 1995.

[2] R. Zuba, Jugend und Gewalt - Gewalt innerhalb und außerhalb der Schule, Studie des Österreichischen Instituts für Jugendforschung 2006. 